\title{
A novel oestrogen-regulated gene in human breast cancer cells identified by differential display
}

\author{
R Stephen, D Corcoran and P D Darbre
}

Division of Cell and Molecular Biology, School of Animal and Microbial Sciences, The University of Reading, PO Box 228, Whiteknights, Reading, RG6 6AJ, UK

(Requests for offprints should be addressed to P D Darbre)

\begin{tabular}{|c|c|}
\hline ABSTRACT & $\begin{array}{l}\text { isolated by differential display has } 100 \% \text { homology from } \\
\text { nucleotides } 615 \text { to } 859 \text { of the published sequence for the }\end{array}$ \\
\hline $\begin{array}{l}\text { Screening by differential display of oestrogen-sensitive MCF7 } \\
\text { human breast cancer cells grown in the short-term ( } 6 \text { days) and } \\
\text { long-term ( } 70 \text { weeks) absence of oestrogen has led to the } \\
\text { identification of a new oestrogen-regulated mRNA. The cDNA }\end{array}$ & $\begin{array}{l}\text { mRNA for human megakaryocyte CD } 63 \text { antigen but has a } 3 \\
\text { tail extended by } 23 \text { nucleotides. Northern blotting has } \\
\text { confirmed that this mRNA is regulated by oestrogen in both } \\
\text { MCF7 and T47D human breast cancer cell lines. }\end{array}$ \\
\hline
\end{tabular}

\section{INTRODUCTION}

Although considerable progress has been made in recent years in our understanding of the molecular action of oestrogen (Parker 1991), the number of identified target genes for oestrogen action remains small, particularly in relation to oestrogen regulation of cell growth. This is of special importance to breast cancer where markers of oestrogen action are needed to identify subsets of tumours with differing sensitivities to endocrine therapy (Miller 1996). Oestrogen has been known for some time to regulate expression of the genes for progesterone receptor (Horwitz \& McGuire 1978), pS2 (Brown et al. 1984) and cathepsin D (Morisset et al. 1986). More recently, levels of mRNA and protein for several growth factors, their receptors and their binding proteins have been shown to be regulated by estrogen (Gee et al. 1996) as have members of the cyclin family, particularly cyclin D1 (Altucci et al. 1996).

We have shown previously that long-term growth of oestrogen-sensitive human breast cancer cell lines in the absence of oestrogen can result in progression to oestrogen independent cell growth without the loss of functional oestrogen receptors (Daly \& Darbre 1990). We have used this model system to screen by the differential display technique for mRNA which are differentially regulated. This has resulted in the identification of a new oestrogen-regulated mRNA which has extensive homology to the mRNA for the CD63 cell surface antigen, a member of the newly identified transmembrane-4-superfamily (TM4SF).

\section{MATERIALS AND METHODS}

\section{Cell lines}

MCF7 McGrath human breast cancer cells were a gift from Dr K Osborne (Osborne et al. 1987) and are a line of cells dependent on oestrogen for cell growth (Darbre \& Daly 1989). T47D human breast cancer cells were a gift from the originators of the line (Keydar et al. 1979) and are a line of cells capable of growth in the absence of oestradiol but showing increased proliferation rate in the presence of oestradiol (Darbre \& Daly 1989). MDA-MB-231 human breast cancer cells were obtained from the American Type Tissue Culture Collection (ATCC, Rockville, MD) and are a line of cells lacking oestrogen receptors.

\section{Culture of stock cells}

Stock MCF7 McGrath cells were grown as monolayer cultures in Dulbecco's modified Eagle's medium (DMEM) (Gibco BRL) supplemented with $5 \%$ foetal calf serum (FCS) (Gibco BRL), $10^{-8} \mathrm{M}$ oestradiol (Steraloids, Croydon, England) and 10 $\mu \mathrm{g} / \mathrm{ml}$ insulin (Sigma, Poole, England) in a humidified atmosphere of $10 \%$ carbon dioxide in air at $37^{\circ} \mathrm{C}$. Oestradiol was dissolved in ethanol and diluted $1 / 10,000$ in culture medium. T47D cells were grown as for MCF7 cells except for the omission of insulin and MDA-MB-231 cells were grown as for MCF7 cells except for the omission of both insulin and oestradiol. All cell stocks were subcultured at weekly intervals by suspension with $0.06 \%$ trypsin- $0.02 \%$ EDTA (pH7.3).

Stock steroid-depleted cells were generated by the growth of cells as stock monolayer cultures as above but in phenol red-free RPMI 1640 medium with 5\% dextran-charcoal stripped FCS (DCFCS) for periods in excess of one year (Daly \& Darbre 1990).

\section{RNA preparation}

Cells for RNA extraction were suspended in phenol red-free RPMI 1640 medium containing 5\% DCFCS at a concentration of $0.2 \times 10^{5}$ cells $/ \mathrm{ml}$ and plated in $16 \mathrm{ml}$ aliquots into $9 \mathrm{~cm}$ 
plastic tissue culture dishes (Nunc) in phenol red-free RPMI 1640 medium supplemented with 5\% DCFCS either without or with $10^{-8} \mathrm{M}$ oestradiol for the required length of time. Cells were washed in situ with isotonic saline, harvested into icecold isotonic saline using a rubber policeman and pelleted by centrifugation. Whole cell RNA was prepared by the guanidinium-caesium chloride ultracentrifugation method (Sambrook et al. 1989).

\section{Differential display}

Differential display was performed using the GenHunter commercial kit (Biogene). Briefly, whole cell RNA was used to provide mRNA for the reverse transcription reaction in which oligo-dT primers anchored to the beginning of the poly(A) tail were used. The following PCR reactions used a second 10 mer arbitrary in sequence. The PCR reaction products were subjected to polyacrylamide gel electrophoresis on a DNA sequencing gel and visualised by autoradiography. Bands of interest were eluted from the gel and eluted DNA subjected to a further round of PCR. PCR products were purified on agarose gel electrophoresis and eluted DNA bands cleaned using a commercial DNA purification kit (Qiagen). DNA was cloned into the pGEM-T vector system (Promega) and amplified in DH5 $\alpha$ bacteria. Plasmid preparations were prepared using a commercial kit following the manufacturer's instructions (Qiagen) and DNA sequencing performed on a Pharmacia-Biotech ALFexpress DNA sequencing machine.

\section{Northern blotting}

Total cellular RNA was subjected to electrophoresis in $1.5 \%$ agarose-formaldehyde gels (Sambrook et al. 1989) at $20 \mu \mathrm{g}$ RNA per track. RNA was transferred onto Hybond-N membranes (Amersham International) and hybridized to $10^{6}$ c.p.m. of ${ }^{32} \mathrm{P}$ labelled DNA probe per $\mathrm{ml}$ according to established protocols (Sambrook et al. 1989). The pS2 DNA probe was a $300-b p$ PstI fragment from $\mathrm{pS} 2$ cDNA (Masiakowski et al. 1982) and the 36B4 control DNA probe was a 220-bp Pst1 fragment (Brown et al. 1984). DNA probes were prepared as DNA segments free of plasmid sequences and were ${ }^{32} \mathrm{P}$-radiolabelled by random primer extension using a commercial kit (Megaprime, Amersham International). Hybridization was at $42^{\circ} \mathrm{C}$ for $18 \mathrm{~h}$ in $5 \times \mathrm{SSPE} / 5 \times$ Denhardt's solution $/ 50 \%$ formamide $/ 0.5 \%$ SDS $/ 20 \mu \mathrm{g} / \mathrm{ml}$ salmon sperm DNA. Blots were washed at a stringency of $0.1 \times \mathrm{SSPE} / 0.1 \%$ SDS at $65^{\circ} \mathrm{C}$ for $30 \mathrm{~min}$. and autoradiographed on Kodak XAR film with intensifying screens at $-70^{\circ} \mathrm{C}$.

\title{
CD63 601 CGAGAAGGCG ATCCATAAGG AGGGCTGTGT GGAGAAGATT GGGGGCTGGC cDNA GCG ATCCATAAGG AGGGCTGTGT GGAGAAGATT GGGGGCTGGC
}

\author{
CD63 651 TGAGGAAAAA TGTGCTGGTG GTAGCTGCAG CAGCCCTTGG AATTGCTTTT \\ cDNA TGAGGAAAAA TGTGCTGGTG GTAGCTGCAG CAGCCCTTGG AATTGCTTTT
}

$\begin{array}{lr}\text { CD63 } & 701 \text { GTCGAGGTTT TGGGAATTGT CTTTGCCTGC TGCCTCGTGA AGAGTATCAG } \\ \text { cDNA } & \text { GTCGAGGTTT TGGGAATTGT CTTTGCCTGC TGCCTCGTGA AGAGTATCAG }\end{array}$

\begin{abstract}
CD63 751 AAGTGGCTAC GAGGTGATGT AGGGGTCTGG TCTCCTCAGC CTCCTCATCT cDNA AAGTGGCTAC GAGGTGATGT AGGGGTCTGG TCTCCTCAGC CTCCTCATCT
\end{abstract}

CD63 801 GGGGGAGTGG AATAGTATCC TCCAGGTTTT TCAATTAAA C GGATTATTTT
cDNA

\author{
CD63 851 TTCAGACCGA AAAAAAAAAA AAAAA \\ cDNA TTCAGACCGA AAAGAGATGGTCTGAGTTTGCCAAAAAAAAAAAAAAA
}

\begin{abstract}
Figure 1. Sequence of a cDNA fragment identified by differential display and relating to an mRNA with altered levels of expression between short-term (6 days) and long-term (70 weeks) oestrogen-deprived MCF7 human breast cancer cells. This cDNA sequence (CDNA) is aligned against the published sequence for human CD63 mRNA (CD63) (Metzelaar et al. 1991). The positions of the primers used are indicated by bold letters underlined. The termination codon is indicated by bold letters enlarged without underlining. The polyadenylation signal is given by enlarged letters underlined.
\end{abstract}




\section{RESULTS}

mRNA for differential display was isolated from MCF7 human breast cancer cells grown as oestrogen-maintained cultures or as short-term (6 days) oestrogen-deprived cultures or as longterm (70 weeks) oestrogen-deprived cultures. Using the primers T12MG and AP5 (5'-GTTGCGATCC-3'), differential display yielded one band reduced in cells deprived of steroid in the long term as compared with short term deprivation. This result was confirmed by three separate experiments. The cDNA band generated from mRNA following short-term steroid deprivation was cut from the gel, cloned into pGEM-T, sequenced, and was found to be 268 nucleotides long. Computer search showed that it had $100 \%$ homology with the published sequence for human CD63 mRNA (Metzelaar et al. 1991) from nucleotides 615 to 859 . The remaining 23 nucleotides at the $3^{\prime}$ end of our cDNA clone extended beyond the published polyA sequence for CD63 mRNA from megakaryocytes (Metzelaar et al. 1991) but aligned with the genomic sequence for human CD63 (Hotta et al. 1992) indicating an extended mRNA. The sequence of our cDNA clone aligned against the published human CD63 mRNA sequence is given in figure 1 . The cDNA homology with CD63 runs from the 3 ' end of the mRNA through the polyadenylation signal (AATTAAA) at position 833-839, through the termination codon at position $770-772$ and back through the protein coding region to position 615 .

This cDNA was then used in Northern blotting experiments to ascertain regulation of the mRNA. Figure 2 shows patterns of oestrogen regulation of this mRNA in three human breast cancer cell lines alongside regulation patterns for the established oestrogen-regulated pS2 mRNA and control unregulated 36B4 mRNA. Our cDNA detected a single mRNA species which appeared with similar sensitivity in MCF7 cells to $\mathrm{pS} 2$ and 36B4 mRNAs. Figure 2 shows that levels of the CD63 mRNA in MCF7 cells fall upon oestrogen withdrawal for one week (Figure 2; tracks 1,2) and fall still further after 92 weeks of oestrogen deprivation (Figure 2; track 3). Readdition of oestrogen to the cells resulted in recovery of the mRNA (Figure 2; tracks 4-7). These patterns of CD63 expression mirrored expression patterns of pS2 mRNA in the MCF7 cells.

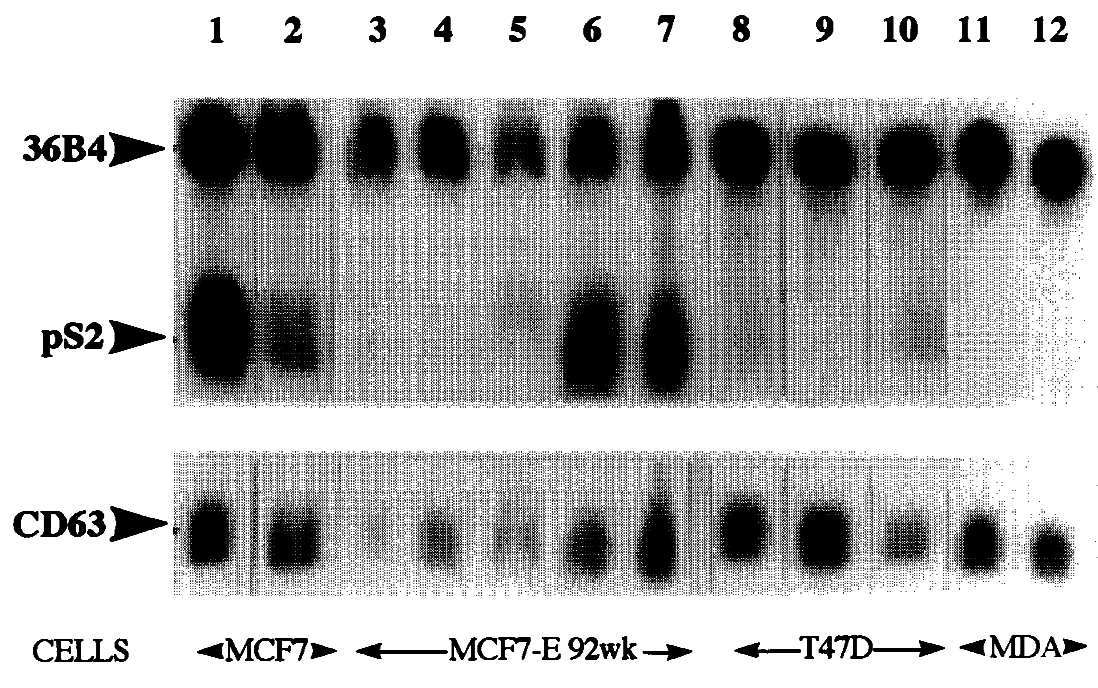

Figure 2. Oestrogen regulation of mRNA detected by our CD63 CDNA in MCF7McGrath and T47D oestrogen-responsive human breast cancer cells and in MDA-MB-231 oestrogen-unresponsive human breast cancer cells. Northern blots of whole cell RNA were probed for expression of CD63 mRNA with our cDNA probe, expression of oestrogen-regulated pS2 mRNA and expression of the control non-oestrogen-regulated 36B4 mRNA. Stock oestrogen-maintained MCF7 McGrath cells were grown for 6 days in phenol-red-free RPMI 1640 medium $/ 5 \%$ DCFCS with $10^{-8} \mathrm{M}$ oestradiol (track 1) or without oestradiol (track 2). Stock oestrogen-maintained MCF7 McGrath cells were grown for 92 weeks in phenol-red-free RPMI 1640 medium $/ 5 \%$ DCFCS (track 3 ) followed by the readdition of $10^{-8} \mathrm{M}$ oestradiol for $1 \mathrm{~h}$ (track 4), $6 \mathrm{~h}$ (track 5), $24 \mathrm{~h}$ (track 6) or 7 days (track 7). Stock oestrogen-maintained T47D cells were grown in phenol-red-free RPMI 1640 medium $/ 5 \%$ DCFCS either for 6 days with $10^{-8} \mathrm{M}$ oestradiol (track 8), without oestradiol (track 9) or for 49 weeks without oestradiol (track 10). Stock MDA-MB-231 cells were grown in RPMI 1640 medium/5\%DCFCS without oestradiol (track 11) or with $10^{-8} \mathrm{M}$ oestradiol (track 12). 
However, although $\mathrm{pS} 2$ is not expressed in either T47D oestrogen responsive cells nor in oestrogen-insensitive MDAMB-231 cells, CD63 mRNA was detectable (Figure 2; tracks $8-12$ ). In the oestrogen responsive T47D cells, CD63 mRNA levels did not drop obviously after one week of oestrogen withdrawal but did drop after longer term 49 week steroid withdrawal (Figure 2; tracks 8-10). In MDA-MB-231 cells, the CD63 mRNA was unregulated as would be expected for cells which lack oestrogen receptors (Figure 2; tracks 11-12).

\section{DISCUSSION}

These results show that expression of the CD63 antigen gene is influenced by oestrogen in oestrogen-responsive human breast cancer cells. Expression of CD63 is not related per se to hormone sensitivity because, unlike $\mathrm{pS} 2$, it is expressed in all the human breast cancer cell lines tested, whether oestrogen sensitive or insensitive. However, in the hormone responsive lines, the level of its expression is reduced upon withdrawal of oestrogen. pS2 remains the classically oestrogen-regulated gene since regulation is at a transcriptional level through estrogen response elements (ERE) in the vicinity of the gene (Berry et al. 1989) but anomolies remain in situations such as T47D cells where pS2 is not expressed at all despite the cells being otherwise oestrogen responsive for growth, and in other cells where its expression turns constitutive despite retention of the oestrogen regulation of other genes (Darbre \& Daly 1989). Whether the oestrogen regulation of CD63 in the hormone sensitive cells is directly at a transcriptional level or indirect through secondary routes remains to be determined. It is possible that regulation of CD63 could be related to the proliferation effects of oestrogen in the cells and indeed other growth-related genes such as c-myc can be induced within minutes of administration of oestrogen (Dubik \& Shiu 1988). On the other hand, computer search of the human CD63 genomic sequence (Hotta et al. 1992) shows that there is an ERE half-site (AGGTCA) (at 921-926) 5' to the start site of the coding region (at 1327) and also an AP1 binding site 5 ' to the gene (at 529-536). Functionality of ERE half-sites has been reported upstream of other genes (Tora et al. 1988, Gill \& Christakos 1995, Rishi et al. 1995) and interactions between an ERE half-site and API have been reported in oestrogen regulation of the ovalbumin gene (Gaub et al. 1990). However, interactions between oestrogen and API have also been described more recently to operate through AP1 sequences (Paech et al. 1997).

It is also interesting that there are additional bases at the $3^{\prime}$ end of the CD63 transcript prior to the poly A tail in the MCF7 human breast cancer cells compared with the published sequence from megakaryocytes. The polyadenylation signal in the MCF7 cells was the same sequence as in the megakaryocytes but of the form AATTAAA rather than the classical AATAAA. However, the MCF7 cells had 43 bases rather than 20 bases as in the megakaryocytes between the polyadenylation signal and the polyadenylation site. Such alterations could influence mRNA stability or translation (Jacobson and Peltz 1996) but any effect in the MCF7 cells remains to be determined. Since the CD63 sequence was determined by elution of the cDNA from short-term ( 6 day) oestrogen-deprived MCF7 cells, it will be interesting to determine any alterations induced by oestrogen treatment or by longer term oestrogen deprivation, especially in view of reports that differential polyadenylation may play a role in oestrogen regulation of mRNA stability (Pastori et al. 1990 and 1992).

The CD63 antigen was originally described as a marker of blood platelet activation (Nieuwenhuis et al. 1987) and was subsequently shown by cDNA sequencing (Metzelaar et al. 1991) to be identical to the human melanoma-associated antigen ME491(Hotta et al. 1988). This antigen belongs to the newly identified transmembrane 4 superfamily of membrane proteins including CD9, CD37, CD53, CD81 and CD82 (Lanza et al. 1991, Classon et al. 1989, Angeliscova et al. 1990, Oren et al. 1990, Gil et al. 1992 respectively). Their function remains largely unknown but CD63 has been suggested to have a role in signal transduction (Skubitz et al. 1996) through PI4kinase (Berditchevski et al. 1997) and in cell motility through interaction with betal integrins (Radford et al. 1997). In the melanoma cells, CD63 has been shown to be a molecular marker of early stages of melanoma progression (Hotta et al. 1988) where it may act as a tumour suppressor gene (Hotta et al. 1991) to limit progression and invasion (Radford et al. 1995). In this respect, it is very interesting that expression of the CD63 is reduced in the long-term steroid deprived cells which provide a model system for the progression to steroid independent growth (Daly \& Darbre 1990). Only time will tell whether it can provide a useful marker for breast tumour progression.

\section{ACKNOWLEDGEMENTS}

This research was supported financially by the Felix Trust and an ORS award (RS).

\section{REFERENCES}

Altucci L, Addeo R, Cicatiello L, Dauvois S, Parker MG, Truss M, Beato M, Sica V, Bresciani F \& Weisz A 199617 beta-Estradiol induces cyclin D1 gene transcription, p36D1-p34cdk4 complex activation and $\mathrm{p} 105 \mathrm{Rb}$ phosphorylation during mitogenic stimulation of G(1)-arrested human breast cancer cells. Oncogene 12 2315-2324

Angelisova P, Vlcek C, Stefanova I, Lipoldova M \& Horejsi V 1990 The human leukocyte surface antigen CD53 is a protein structuratly similar to the CD37 and MRC OX-44 antigens. Immunogenetics 32 281-285.

Berditchevski F, Tolias KF, Wong K, Carpenter CL \& Hemler ME 1997 A novel link between integrins, transmembrane-4 superfamily proteins (CD63 and CD81) and phosphatidylinositol-4kinase. Journal of Biological Chemistry 272 2595-2598.

Berry M, Nunez AM \& Chambon P 1989 Estrogen-responsive element of the human $\mathrm{pS} 2$ gene is an imperfectly palindromic sequence. 
Proceedings of the National Academy of Sciences of the USA 86 1218-1222.

Brown AMC, Jeltsch JM, Roberts M \& Chambon P 1984 Activation of pS2 gene transcription is a primary response to estrogen in the human breast cancer cell line MCF-7. Proceedings of the National Academy of Sciences of the USA 81 6344-6348.

Classon BJ, Williams AF, Willis AC, Seed B \& Stamenkovic I 1989 The primary structure of the human leukocyte antigen CD37, a species homologue of the rat MRC OX-44 antigen. Journal of Experimental Medicine 169 1497-1502.

Daly RJ \& Darbre PD 1990 Cellular and molecular events in loss of estrogen sensitivity in ZR-75-1 and T-47-D human breast cancer cells. Cancer Research 50 5868-5875.

Darbre PD \& Daly RJ 1989 Effects of oestrogen on human breast cancer cells in culture. Proceedings of the Royal Society of Edinburgh 95B 119-132.

Dubik D \& Shiu RPC 1988 Transcriptional regulation of c-myc oncogene expression by estrogen in hormone-responsive human breast cancer cells. Journal of Biological Chemistry 26312705 12708.

Gaub MP, Bellard M, Scheuer I, Chambon P \& Sassone-Corsi P 1990 Activation of the ovalbumin gene by the estrogen receptor involves the fos-jun complex. Cell 63 1267-1276.

Gee JMW, McClelland RA \& Nicholson RI 1996 Growth factors and endocrine responsiveness in breast cancer. In Hormone-dependent Cancer, pp169-197. Eds JR Pasqualini \& BS Katzenellenbogen. New York: Marcel Dekker Inc.

Gil ML, Vita N, Lebel-Binay S, Miloux B, Chalon P, Kaghad M, Marchiol-Fournigault C, Conjeaud H, Caput D, Fcrrara P, Fradelizi D \& Quillet-Mary A 1992 A member of the tetraspans transmembrane protein superfamily is recognized by a monoclonal antibody raised against an HLA class I-deficient, lymphokineactivated killer-susceptible, B lymphocyte line. Joumal of Immunology 148 2826-2833.

Gill RK \& Christakos S 1995 Regulation by estrogen through the 5'flanking region of the mouse calbindin-D28k gene. Molecular Endocrinology 9 319-326.

Horwitz KB \& McGuire WL 1978 Estrogen control of progesterone receptor in human breast cancer. Journal of Biological Chemistry $2532223-2228$.

Hotta H, Ross AH, Huebner K, Isobe M, Wendeborn S, Chao MV, Ricciardi RP, Tsujimoto Y, Croce CM \& Koprowski H 1988 Molecular cloning and characterisation of an antigen associated with early stages of melanoma tumor progression. Cancer Research 48 2955-2962.

Hotta H, Hara I, Miyamoto H \& Homma M 1991 Overexpression of the human melanoma-associated antigen ME491 partially suppresses in vivo malignant phenotypes of H-ras-transformed NIH3T3 cells in athymic nude mice. Melanoma Research 1125 132.

Hotta H, Miyamoto H, Hara I, Takahashi N \& Homma M 1992 Genomic structure of the ME491/CD63 antigen gene and functional analysis of the 5'-flanking regulatory sequences. Biochemical and Biophysical Research Communications 185 436442.

Jacobson A \& Peltz SW 1996 Interrelationships of the pathways of mRNA decay and translation in eukaryotic cells. Annual Review of Biochemistry 65 693-739.

Keydar I, Chen L, Karby S, Weiss FR, Delarea J, Radu M, Chaitcik S \& Brenner HJ 1979 Establishment and characterisation of a cell line of human breast carcinoma origin. European Journal of Cancer 15 659-670.

Lanza F, Wolf D, Fox CF, Kieffer N,Seyer JM, Fried VA, Coughlin SR, Phillips DR \& Jennings LK 1991 cDNA cloning and expression of platelet p24/CD9. Evidence for a new family of multiple membrane-spanning proteins. Journal of Biological Chemistry 266 10638-10645.

Masiakowski P, Breathnach R, Bloch J, Gannon F, Krust A \& Chambon P 1982 Cloning of cDNA sequences of hormoneregulated genes from the MCF-7 human breast cancer cell line. Nucleic Acids Research 10 7895-7903.

Metzelaar MJ, Wijngaard PL, Peters PJ, Sixma JJ, Nieuwenhuis HK \& Clevers HC 1991 CD63 antigen. A novel lysosomal membrane glycoprotein, cloned by a screening procedure for intracellular antigens in eukaryotic cells. Journal of Biological Chemistry 266 3239-3245.

Miller WR 1996 Estrogen and Breast Cancer. London: Chapman and Hall.

Morisset M, Capony F \& Rochefort H 1986 The 52-kDa estrogeninduced protein secreted by MCF7 cells is a lysosomal acidic protease. Biochemical and Biophysical Research Communications 138 102-109.

Nieuwenhuis HK, van Oosterhout JJG, Rozemuller E, van Iwaarden F \& Sixma JJ 1987 Studies with a monoclonal antibody against activated platelets: evidence that a secreted 53,000-molecular weight lysosome-like granule protein is exposed on the surface of activated platelets in the circulation. Blood 70 838-845.

Oren R, Takahashi S, Doss C, Levy R \& Levy S 1990 TAPA-1, the target of an antiproliferative antibody, defines a new family of transmembrane proteins. Molecular and Cellular Biology 10 $4007-4015$.

Osborne CK, Hobbs K \& Trent JM 1987 Biological differences among MCF-7 human breast cancer cell lines from different laboratories. Breast Cancer Research 9 111-121.

Paech K, Webb P, Kuiper GG, Nilsson S, Gustafsson J, Kushner PJ \& Scanlan TS 1997 Differential ligand activation of estrogen receptors ERalpha and ERbeta at AP1 sites. Science 277 15081510.

Parker MG (editor) 1991 Nuclear Hormone Receptors. London: Academic Press.

Pastori RL, Moskaitis JE, Smith LH \& Schoenberg DR 1990 Estrogen regulation of Xenopus laevis gamma-fibrinogen gene expression. Biochemistry 29 2599-2605.

Pastori RL, Moskaitis JE, Buzek SW \& Schoenberg DR 1992 Differential regulation and polyadenylation of transferrin mRNA in xenopus liver and oviduct. Journal of Steroid Biochemistry and Molecular Biology 42 649-657.

Radford KJ, Mallesch J \& Hersey P 1995 Suppression of human melanoma cell growth and metastasis by the melanoma-associated antigen CD63 (ME491). International Joumal of Cancer 62 631635 .

Radford KJ, Thorne RF \& Hersey P 1997 Regulation of tumor cell motility and migration by CD63 in a human melanoma cell line. Joumal of Immunology 158 3353-3358.

Rishi AK, Shao ZM, Baumann RG, Li XS, Sheikh MS, Kimura S, Bashirelahi N \& Fontana JA 1995 Estradiol regulation of the human retinoic acid receptor alpha gene in human breast carcinoma cells is mediated via imperfect half-palindromic estrogen response element and $\mathrm{Sp} 1$ motifs. Cancer Research 55 4999-5006. 
Sambrook J, Fitsch EF \& Maniatis T 1989 Molecular Cloning: A Laboratory Manual. New York: Cold Spring Harbor Laboratory Press.

Skubitz KM, Campbell KD, Iida J \& Skubitz APN 1996 CD63 associates with tyrosine kinase activity and CD11/CD 18, and transmits an activation signal in neutrophils. Joumal of Immunology 157 3617-3626.
Tora L, Gaub MP, Mader S, Dierich A, Bellard M \& Chambon P 1988 Cell-specific activity of a GGTCA half-palindromic oestrogenresponsive element in the chicken ovalbumin gene promoter. Embo Journal 7 3771-3778. 